\title{
Cost channel in the mechanism of transmitting monetary policy in Poland
}

\author{
Magdalena Redo \\ Department of International Security, \\ Nicolaus Copernicus University in Toruń \\ Poland \\ dynus@umk.pl \\ Piotr Siemiątkowski \\ Department of Political Systems, \\ Nicolaus Copernicus University in Toruń \\ Poland \\ piotrs@umk.pl
}

Abstract. The aim of the present paper is the analysis of the Received: February, 2019 1st Revision:

May, 2019

Accepted: mechanism of transmitting a monetary policy into the Polish economy as well as the attempt to assess its strengths. To accomplish the above-stated goal, one attempted to solve the October, 2019 following two research problems: is the cost channel operative in Poland patent and what is its strength and efficiency? What was also analysed is the correlation between the level of the benchmark rate of the National Bank of Poland [hereinafter also referred to as $8330.2019 / 12-4 / 9$ NBP] and the value of the working capital relative to current assets and to sales revenues made by the business enterprises in Poland in the period 2005-2017. By analogy, what was also subject to correlation analysis was the relation between the base interest rate of the National Bank and the value of investment expenditures in Poland. At the next stage, via an inductive method, one conducted a synthesis of the conclusions obtained by way of a comparative analysis of the results of one's own research against the backdrop of the ones obtained by way of the analysis of the influence of a monetary policy exerted on the supply side of an economy, with the latter results having been obtained in consequence of global econometric research. The correlation analysis thus conducted seems to corroborate the influence of the monetary policy pursued by the National Bank of Poland on real economic indices in Poland; and, strictly speaking, on financial 
policies of companies. Any change in the interest rates of banks seems to significantly influence the cost of the companies' maintaining working capital. The research results presented herein are exceptionally important from the point of view of the efficacy of a monetary policy. In the process of designing it, the central bank should take into consideration any additional supply effects. In connection with the strongly positive correlation, as demonstrated in the present paper, between the value of the working capital and investment expenditures and the level of interest rates, it is necessary to have a better grasp of the mechanism of cost channel in a given economy as well as to do the ongoing monitoring thereof.

Keywords: cost channel, monetary policy, mechanism of transmitting.

JEL Classification: E52, E58

\section{INTRODUCTION}

Monetary policy affects not only the demand side of an economy but also its supply side. It is because a monetary policy exerts influence on the level of cost incurred by business enterprises. The mechanism by way of which a central bank affects the financial cost incurred by business enterprises and thus their respective marginal costs and eventually, in consequence, the price and production levels is referred to as 'cost channel' in the mechanism of transmitting impulses of monetary policy into an economy (Barth \& Ramey, 2000; Delia Chang \& Jansen, 2014).

The more and more numerous results of the research confirming the efficacy of the cost channel point to a necessity of taking into consideration the functioning of this mechanism as far as the analysis of the consequences of employing the means of monetary policy is concerned (Adolfson, Lindé, Laséen \& Villani, 2005; Barth \& Ramey, 2000; Chowdhury, Hoffmann, \& Schabert, 2006; Christiano, Eichenbaum \& Evans, 2005; Dedola \& Lippi, 2005; Delia Chang \& Jansen, 2014; Gaiotti \& Secchi, 2004; Goodhart, 1986; Henzel, Hülsewig, Mayer, \& Wollmershäuser, 2009; Hicks, 1979; Kilponen \& Milne, 2007; Mallik \& Chowdhury, 2001; Ravenna \& Walsh, 2006; Silva, Paes \& Bezerra, 2016; Tillmann, 2008). This allows for a more accurate prediction of the effects of the means that a given monetary employs under the condition of ever-evolving economic processes, which would simultaneously allow for identifying more efficient solutions. The research in question neither denies nor diminishes the role played by the demand-siderelated channels of the transmission of a monetary policy (Redo, 2018b). Rather, this research supplements them with supply-related mechanisms which were earlier unheeded while analyzing the influence of a monetary policy on real economic indices. The results of this research indicate that the functioning of the cost channel strengthens the well-known demand effects (that is, production response) and alters price effects; that is, it decreases the volume of production as a result of tightening a monetary policy and/or weakens its anti-inflationary effects and strengthens pro-production and/or pro-inflationary effects of decreases in a central bank's interest rates (Bunea \& Dinu, 2019; Jędrzejowska-Schiffauer \& Schiffauer, 2016).

That is why, a central bank should in its decisions take heed of the fact of existence of the cost channel and adjust its responses as well as the means employed according to the scales and the power of influence of the cost channel under consideration. In order to do so, what is necessary is the ongoing monitoring of the mechanism of transmitting impulses of a monetary policy into an economy as well as of 
the factors determining the patency of the said cost channel. The factors thereby meant are such that may permanently or temporarily affect the so-far functioning of the cost channel, and thus of the entire mechanism of the transmission of a monetary policy (the effects of the actions taken by a central bank), thereby restricting the efficacy of the said policy. The above-mentioned factors comprise what follows:

- the situation and changes both on the domestic and international financial market (Redo \& Siemiątkowski, 2017);

- on the financial and capital account of the balance of payments (Siemiatkowski, 2016, 2017);

- in the amount, cost and availability of capital on the domestic markets and on foreign ones (Redo, 2017);

- in the structure, strength and financial-capital situation of bank sector;

- in how the banks' tendency to expand credits varies depending on the changes in the central bank's interest rates;

- in the fluctuations of an economic situation (Cieślik et al., 2015; Redo, 2015);

- in the market interest rate and the variation therein (Redo, 2013);

- in the strength, pace, completeness and asymmetry of pass-through effect of a monetary policy relative to the situation on the domestic loan market;

- in the financial-capital situation of business enterprises;

- in their dependence on the external sources of funding and the demand for working capital (Siemiątkowski, 2014; Siemiatkowski \& Jankowska, 2013);

- in their dependence on the bank credit;

- in the availability of alternative sources of funding (especially short-term ones);

- in the characteristic of monetary policies pursued by respective companies;

- in the level of the fixity of prices and in its asymmetry;

- in the regime of currency exchange and in its stability (Zablotska, 2013);

- and finally, in legal regulations and in the instruments availed of by an economic policy which can either solidify or weaken the efficacy of the cost channel of a monetary policy as well as in all the other factors able to aggravate (or mitigate) the difficulties in accessing the sources of funding business enterprises and/or banks, and thereby to enhance (or weaken) the strength of the impulses of a monetary policy exerting some influence on an economy, while simultaneously decreasing its efficiency (Redo, 2016b).

Due to the complexity of economic mechanisms, one is unable to pinpoint all the determining factors of the efficiency of the cost channel. Therefore, what one is left with is to exercise a sound judgement as to which of these factors play a crucial role in terms of the patency of the cost channel in a given economy. Furthermore, one must judge in case of which of the said factors the occurring changes may distort the efficacy of a monetary policy. The above should be heeded while specifying one's monetary policy (Redo, 2016a).

Tightening a monetary policy after all causes an increase in the cost of foreign capital (e.g. working capital facility). It is business enterprises that are forced to avail themselves of this capital due to prefinancing their respective business operations, that is, incurring cost stemming from purchasing materials, semi-products or incurring overheads before their respective accounts are credited with the amounts payable for the products they managed to sell. An increase in financial cost triggers an increase in marginal cost and may lead up to an increase in prices and to the restriction of the volume of production, thus 
partly explaining the phenomenon of price puzzlet - that is, of the increase in prices due to increasing interest rates (Eichenbaum, 1992; Sims, 1992).

At this point, it should be stressed that the above phenomenon occurs also in the case of business enterprises which do not resort to foreign capital since as bank loan interest rates grow so does the opportunity cost of one's equity, thus also giving rise to an increase in marginal costs. That is why, to take into consideration the variability of business enterprises' demand for capital (regardless whether it is domestic or foreign one), and in the light of a variable length of a cash conversion cycle ${ }^{2}$, Barth, Ramey (Barth \& Ramey, 2000) suggested focusing on the analysis of the influence of the changes in a central bank's interest rates upon the value of the cost of working capital ${ }^{3}$. This capital is a pre-requisite for a company's liquidity, while also increasing the financial stability thereof. However, this capital is (under normal circumstances) a more expensive capital than a short-term foreign capital. And hence, the capital under scrutiny is highly sensitive to all sorts of tensions - for instance, to tightening a monetary policy. For this reason, in the mainstream subject-matter literature, one may encounter the phrase working capital channel - see: (Adolfson et al., 2005; Christiano et al., 2005).

\section{METHODOLOGY}

The aim of the present paper is to analyse the functioning of the cost channel (of working capital) in the mechanism of transmitting a monetary policy into the Polish economy in the period 2005-2017 as well as to attempt to assess its strength. The two following research problems were defined:

P1: is the cost channel in Poland patent?

P2: what is its efficacy?

Furthermore, the following two hypotheses were stated:

H1: a monetary policy pursed by the National Bank of Poland affects the real indices in an economy.

$\mathrm{H} 2$ : the cost channel in the transmission of a monetary policy in Poland affects the financial decisions taken by respective business enterprises.

To reach the goal set by the present paper, what was conducted was the analysis of the correlation between the benchmark rate of the National Bank of Poland (and the value of working capital relative to current assets and to sales revenues made by business enterprises in Poland (the ones employing over 9 people) in the period 2005-2017. The measure employed was Pearson correlation coefficient. By analogy, what was further subject to correlation analysis was the relation between the level of the base interest rate of NBP and the value of investment expenditures of the business enterprises in Poland in the period 2005-2017 (that is, expenditures for fixed assets relative to overall assets of the business enterprises employing over 9 people). Then, employing the method of inductive reasoning, one conducted a synthesis of the results obtained 1) by way of a comparative analysis of the results of one's own research and the ones obtained via content-related analysis; and 2) by way of an analysis of the results obtained thanks to global econometric research, with this research analysing the influence of a monetary policy on the supply side of an economy.

${ }^{1}$ This anomaly was observed by Sims back in 1992 - among others - in USA, Germany, France, whereas the expression price purzle was coined by Eichenbaum 1992.

${ }^{2}$ Cash conversion cycle is a period between a company's investing for the sake of purchasing materials and converting the said investments into cash flows from sales. (see further: Dynus, Kołosowska, \& Prewysz-Kwinto 2005).

${ }^{3}$ Working capital is a long-term capital (in other words: a fixed capital; it may be one's equity and/or a long-term foreign capital) serving to finance current assets (see further: Dynus, Kołosowska, \& Prewysz-Kwinto 2005). 


\section{EMPIRICAL RESULTS AND DISCUSSION}

\subsection{The relation between the benchmark rate of NBP and the value of working capital of the business enterprises in Poland in the period 2005-2017}

The analysis - as conducted herein - of the correlation between the average level of interest rate of NBP (viz., a semi-annual benchmark rate weighted by a number of months of its being in effect) and the value of working capital of the business enterprises in Poland in the period 2005-2017 demonstrated a very strong ${ }^{4}$ negative correlation between these two indices see: Figure 1 and 2 and Table 1).

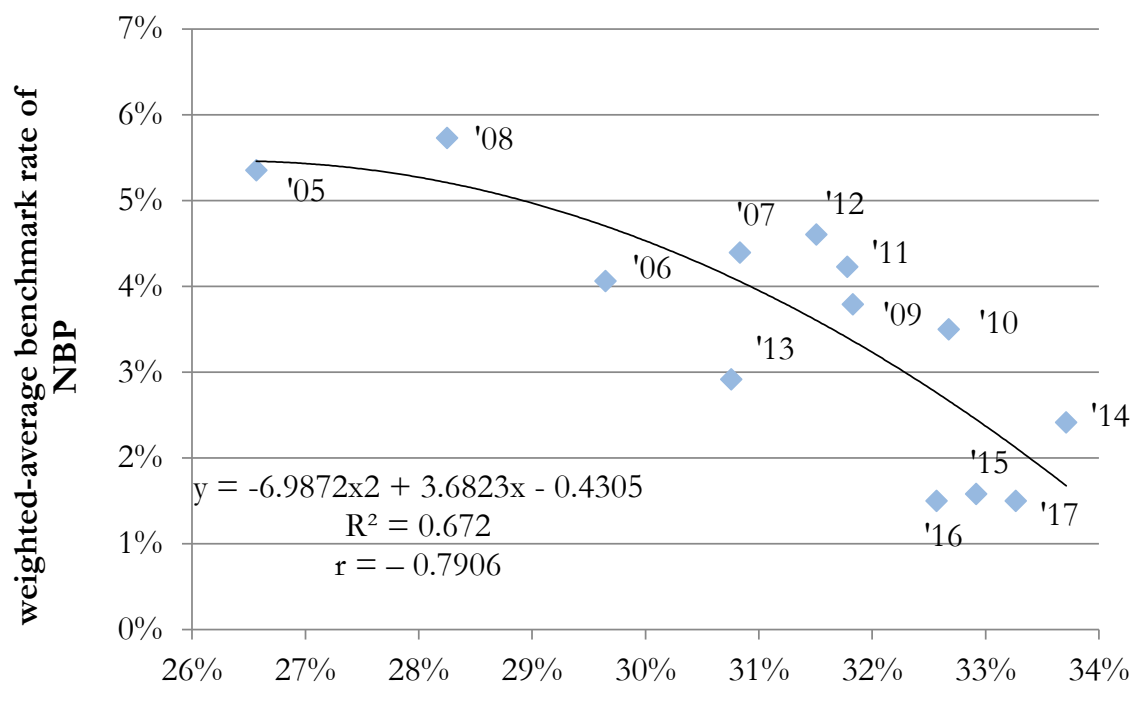

relation of working capital to current assets

Figure 1. An average level of the benchmark rate* of NBP and the value of working capital** relative to currents assets of the business enterprises*** in Poland in the period 2005-2017

Source: own work on the basis of the data of GUS [Central Statistical Office], Wyniki finansowe podmiotów gospodarcsych. Raporty z lat 2005-2017 [Financial results of business entities. The report from the period 2005-2017] (www.stat.gov.pl - access date 6 September 2018 ) and NBP, Podstawowe stopy procentowe NBP w latach 1998-2017 [Base interest rates of NBP from the period 1998-2017] (www.nbp.pl - access date 6 September 2018).* weighted-average benchmark rate of NBP is a semi-annual benchmark rate of NBP weighted by a number of months of its being in effect** working capital established as a difference between current assets and short-term liabilities*** with the number of employees being more than 9 people

This confirms a negative slope of a relatively well adjusted binomial-trend line both for the average benchmark rate of NBP coupled with the value of working capital relative to current assets in the business enterprises in Poland in the period 2005-2017 (see: Figure 1) and for the average benchmark rate of NBP coupled with the value of working capital relative to their respective sales revenues in the scrutinised period (Figure 2). In the first case, the determination coefficient is $\mathrm{R}^{2}=0.672$, whereas in the other it amounts to $\mathrm{R}^{2}=0.738$. For linear trends, determination coefficients amount to, respectively, 0.625 and 0.705 .

\footnotetext{
${ }^{4}$ According to the classification put forward by J. Guilford.
} 


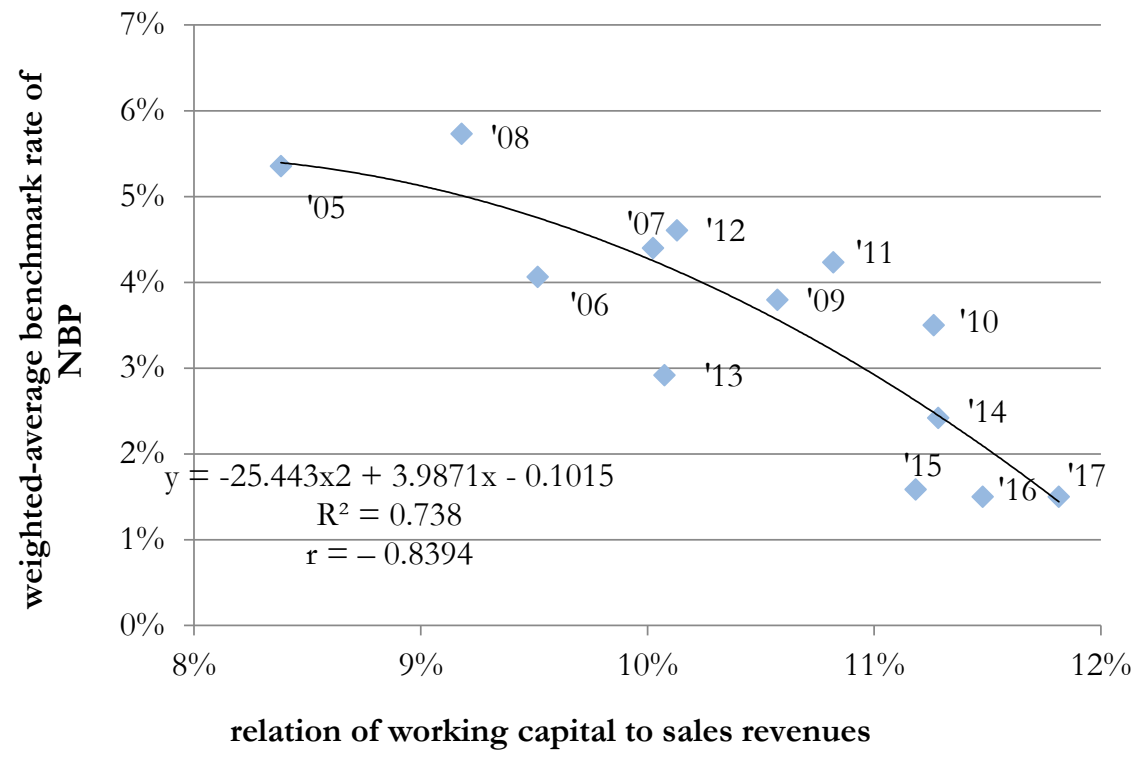

Figure 2. Average level of the benchmark rate* of NBP vis-à-vis the value of working capital** relative to sales revenues of the business enterprises*** in Poland in the period 2005-2017

Source: the same as the one for Figure $1^{*}$ weighted-average benchmark rate of NBP is a semi-annual benchmark rate of NBP weighted by a number of months of its being in effect** working capital established as a difference between current assets and short-term liabilities*** with the number of employees being more than 9 people

Pearson correlation coefficient between an average level of the benchmark rate of NBP and the value of working capital relative to current assets amounted to, in the scrutinised period, -0.79 , and between an average level of the benchmark rate of NBP and the value of working capital relative to sales revenues: -0.84 (see: Table 1). This means that the decrease of interest rate since the outburst of financial crisis of 2008 in USA has been accompanied by the increase of working capital in the business enterprises in Poland. These results seems to confirm the influence of a monetary policy on real economic indices, including the financial policies pursued by respective companies. 
Table 1

The base interest rate of NBP vis-à-vis the value of the maintained working capital of the business enterprises in Poland (with the number of employees being more than 9 people) in the period 2005-2017

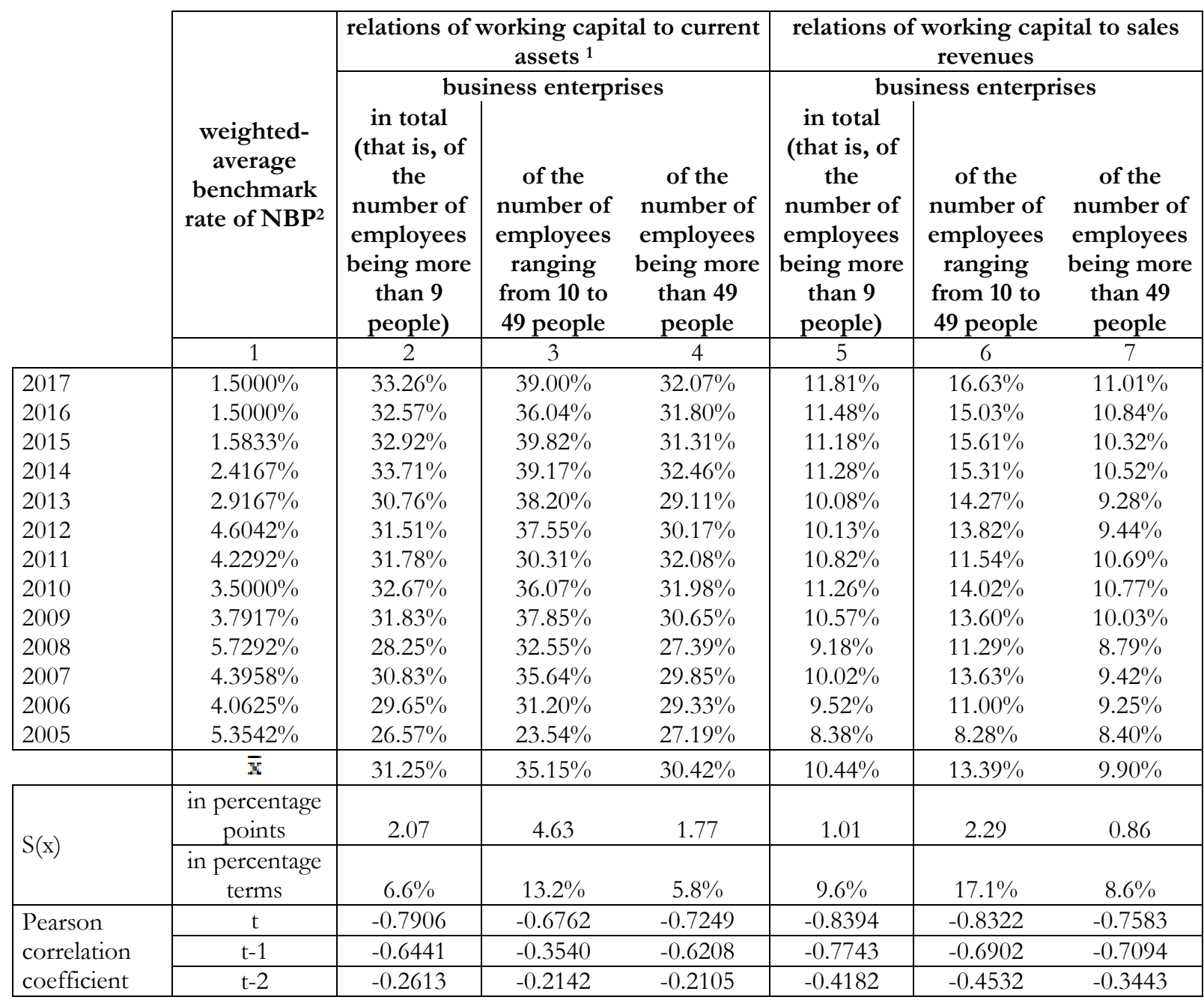

Source: the same as the one for figure 1

${ }^{1}$ working capital as established as a difference between current assets and short-term liabilities

2 weighted-average benchmark rate of NBP is a semi-annual benchmark rate of NBP weighted by a number of months of its being in effect

The analysis of the semi-annual benchmark rate of NBP and the level of working capital in the business enterprises in Poland in the period 2005-2017 indicate that in the case of higher interest rates until the autumn of 2008, the business enterprises in Poland kept a relatively lower working capital - even on the average level of $27-30 \%$ of current assets (and in small businesses in 2005 - even as little as $23.5 \%$ ) and about $8-10 \%$ of the sales revenues; whereas in the last three years (2015-2017), in which the interest rates of NBP have been 3-4 times as low as back then, the working capital was maintained at a considerably higher level of about $33 \%$ of current assets and about $11-12 \%$ of sales revenues (and in small businesses - even on the level of $39-40 \%$ of current assets and about $15-17 \%$ of sales revenues - see: Table 1). 
The above conclusions are confirmed by a more accurate analysis of the indices of the liquidity of the business enterprises in Poland (see: table 2). The average statistics of GUS indicate that especially small and medium-sized businesses are characterized in 2018 by relatively high indices of liquidity.

Table 2

Average level of the indices of liquidity and of working capital (in relation to current assets) of the business enterprises in the first half of $2018^{5}$

\begin{tabular}{|c|c|c|c|c|}
\hline & \multicolumn{3}{|c|}{$\begin{array}{l}\text { index of financial liquidity } \\
\text { (in \%) }\end{array}$} & \multirow{2}{*}{$\begin{array}{l}\text { Working } \\
\text { capital in } \\
\text { relation to } \\
\text { current assets } \\
\text { (in } \%)\end{array}$} \\
\hline & first degree & $\begin{array}{l}\text { second } \\
\text { degree }\end{array}$ & third degree & \\
\hline benchmark rate & 20 & 100 & $120-200$ & $17-50$ \\
\hline business enterprises in total & 36.6 & 101.8 & 148.3 & 32.6 \\
\hline The ones employing 10-49 people & 40.0 & 108.8 & 155.6 & 35.7 \\
\hline The ones employing 50-249 people & 37.7 & 108.9 & 160.8 & 37.8 \\
\hline The ones employing 250 and more people & 35.4 & 97.2 & 141.4 & 29.3 \\
\hline
\end{tabular}

Source: own work on the basis of the data of GUS, Wyniki finansowe podmiotón gospodarcsych I-VI 2018 [Financial results of business entities I-VI 2018].

It should be added that in 2018, the first-degree financial liquidity index above the benchmark rate was instantiated in $49,8 \%$ of business enterprises, and the second-degree liquidity index - in $12.3 \%$ of them (GUS, 2018). This implies that the said businesses (satisfying the above two descriptions) keep a relative higher level of working capital. In the case of small businesses, this capital amounted to - in the first half of 2018 - on average, $35.7 \%$ of their current assets; whereas in the case of medium-sized businesses $-37.8 \%$.

It must be conceded that a higher level of working capital strengthens the financial stability of businesses; however, in the situation of theoretically higher availability of capital and better creditworthiness due to lower interest rates, maintaining higher indices of liquidity (of third degree) may be perceived as evidence of inefficient use of a company's assets. This in turn leads to lower profitability than the one which could be generated by dint of higher prices and/or lower wages. Especially when one compares this with much lower levels of working capital in the business enterprises in Poland before 2008.

Furthermore, one should emphasise that the above differences in the level of the maintained working capital are particularly big in the case of small businesses, which, next to microenterprises, are the major creators of economic growth and of new vacancies. They almost always maintain working capital at a higher and more conservative level (in relation to their respective current assets and sales revenues) than medium-sized and large enterprises (see: columns 3 and 5 as well as 6 and 7 in Table 1). And although this is understandable due to small businesses having worse access to external funding, what is worth noting are disproportions in the levels of the maintained working capital, which additionally worsens their respective competitiveness as compared with larger companies under the circumstances of theoretically lax financial restrictions, with the said circumstances having been in effect for several years. The persistence of, above the established one, a negative correlation between an interest rate and the value of working capital may in the future threaten the financial stability of small businesses in Poland in the situation in which interest rate will start - as expected - to rise.

\footnotetext{
5 The indices were established on the basis of financial statements of 45.2 thousand business entities employing more than 9 people (including 27.9 thousand of small, 13.7 thousand of medium-sized and 3.6 thousand of large businesses).
} 
These are kept in entire Europe as well as in Poland at a historically low level (since March 2015, the benchmark rate of NBP amounts to as little as 1.5\%, whereas in 2008 it equaled as much as $6 \%$ ) as a response to the crisis of 2008. It should be borne in mind that the expected upturn of the global economy and/or the increase of inflation will eventually force interest rates to go up. Especially in the situation in which the major economies with developed financial markets start successively doing so. The fear of capital outflow will also force other states to increase interest rates. This applies especially to developing economies- such as Poland - highly dependent on external funding, with such economies being unable without the funding in question to finance their development and roll their debt. If the above-described dependency persists and the business enterprises in Poland start lowering working capital (and thus the third-degree index of liquidity), then their stability will drop, the risk of losing liquidity will rise as well as a risk premium. Additionally, creditworthiness will drop and so will their credibility as business partners. Eventually, the competitiveness of small businesses will be compromised too. Lower liquidity (lower level of working capital), causing an increase in entrepreneurial risk, additionally affects an optimal profit margin (Barth \& Ramey, 2000). Therefore, business enterprises might be tempted to raise prices according to the functioning of the cost channel. Lower liquidity may also weaken anti-inflationary effects of the increase of a central bank's interest rates; and, what is worse, it may force the central bank to introduce further and more radical increases in interest rates, which will cool an economy down, simultaneously overvaluing cost of capital and suppressing investments.

\subsection{Relation between the benchmark rate of NBP and the value of investment expenditures of the business enterprises in Poland in the period 2005-2017}

Anxiety of financial stability of business enterprises and of economic growth in Poland in the face of the increase of interest rates is additionally aggravated by a relatively strong positive Pearson linear correlation coefficient for the relations between an average benchmark rate of NBP and the value of investment expenditures of business enterprises in Poland in the period 2005-2017: $(r=0.60)$. The value the said coefficient assumed demonstrates that the higher interest rates of NBP - which was due to an economic upturn till 2008 - were accompanied by higher expenditures for fixed assets of the business enterprises in Poland. As opposed to last few years, in which despite a considerable decrease of interest rates by NBP the expenditures for fix assets did not rise accordingly (see Fig. 3 and Tab. 3).

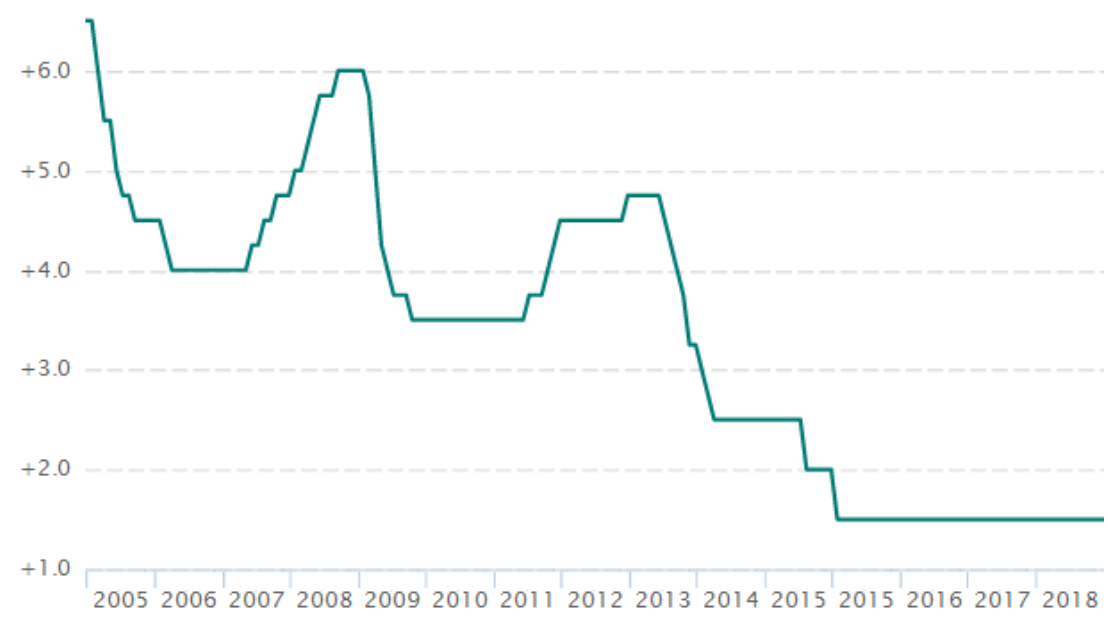

Figure 3. The level of the benchmark rate of NBP in the period 2005-2018 (in \%)

Source: NBP, Podstawowe stopy procentowe NBP na koniec miesiaca [Base interest rates of NBP at the end of a month] 
It should be added that this relation is significantly more tight in the case of small businesses $(\mathrm{r}=0.76)$ and less tight in the case of medium-sized and large ones $(\mathrm{r}=0.54)-$ see: table 3.

Table 3

The level of the base interest rate of NBP vis-à-vis expenditures for fixed assets of the business enterprises in Poland (with the number of their employees being more than 9 people) in the period 2005-

2017

\begin{tabular}{|c|c|c|c|c|}
\hline & \multirow{3}{*}{$\begin{array}{c}\text { Weighted- } \\
\text { average } \\
\text { benchmark rate } \\
\text { of } \text { NBP }^{2}\end{array}$} & \multicolumn{3}{|c|}{ Relation between expenditures for fixed assets to overall assets } \\
\hline & & \multicolumn{3}{|c|}{ Business enterprises } \\
\hline & & $\begin{array}{l}\text { In total (that is, of the } \\
\text { number of employees being } \\
\text { more than } 9 \text { people) }\end{array}$ & $\begin{array}{l}\text { of the number of } \\
\text { employees ranging } \\
\text { from } 10 \text { to } 49 \text { people }\end{array}$ & $\begin{array}{l}\text { of the number of } \\
\text { employees being } \\
\text { more than } 49 \text { people }\end{array}$ \\
\hline 2017 & $1,5000 \%$ & $4.71 \%$ & $2.56 \%$ & $5.06 \%$ \\
\hline 2016 & $1.5000 \%$ & $4.78 \%$ & $2.57 \%$ & $5.15 \%$ \\
\hline 2015 & $1.5833 \%$ & $5.71 \%$ & $3.37 \%$ & $6.12 \%$ \\
\hline 2014 & $2.4167 \%$ & $5.33 \%$ & $3.23 \%$ & $5.70 \%$ \\
\hline 2013 & $2.9167 \%$ & $4.92 \%$ & $3.30 \%$ & $5.19 \%$ \\
\hline 2012 & $4.6042 \%$ & $4.98 \%$ & $3.40 \%$ & $5.25 \%$ \\
\hline 2011 & $4.2292 \%$ & $5.25 \%$ & $4.17 \%$ & $5.42 \%$ \\
\hline 2010 & $3.5000 \%$ & $5.16 \%$ & $4.29 \%$ & $5.30 \%$ \\
\hline 2009 & $3.7917 \%$ & $5.82 \%$ & $4.63 \%$ & $6.01 \%$ \\
\hline 2008 & $5.7292 \%$ & $6.68 \%$ & $5.13 \%$ & $6.93 \%$ \\
\hline 2007 & $4.3958 \%$ & $6.70 \%$ & $4.34 \%$ & $7.09 \%$ \\
\hline 2006 & $4.0625 \%$ & $6.09 \%$ & $4.56 \%$ & $6.35 \%$ \\
\hline \multirow[t]{2}{*}{2005} & $5.3542 \%$ & $5.69 \%$ & $3.69 \%$ & $6.04 \%$ \\
\hline & $\overline{\mathbf{x}}$ & $4.79 \%$ & $3.39 \%$ & $5.03 \%$ \\
\hline \multirow{2}{*}{$S(x)$} & $\begin{array}{l}\text { In percentage } \\
\text { points }\end{array}$ & 0.67 & 0.80 & 0.68 \\
\hline & $\begin{array}{l}\text { In percentage } \\
\text { terms }\end{array}$ & $13.9 \%$ & $23.6 \%$ & $13.5 \%$ \\
\hline \multirow{3}{*}{$\begin{array}{l}\text { Pearson } \\
\text { correlation } \\
\text { coefficient }\end{array}$} & $\mathrm{T}$ & 0.6013 & 0.7591 & 0.5364 \\
\hline & $\mathrm{t}-1$ & 0.5069 & 0.7801 & 0.4236 \\
\hline & $\mathrm{t}-2$ & 0.4742 & 0.6771 & 0.4095 \\
\hline
\end{tabular}

Source: the same as the one for fig.1.

${ }^{2}$ weighted-average benchmark rate of NBP is a semi-annual benchmark rate of NBP weighted by a number of months of its being in effect.

The strong correlation between the said indices in the case of small businesses is represented by the figure depicting data scatter for the average benchmark rate of NBP and for the average level of investment expenditures (for fixed assets) of small businesses in Poland in relation to their respective fixed assets in the period 2005-2017 (see: figure 4). Determination coefficient $\mathrm{R}^{2}=0.594$. 


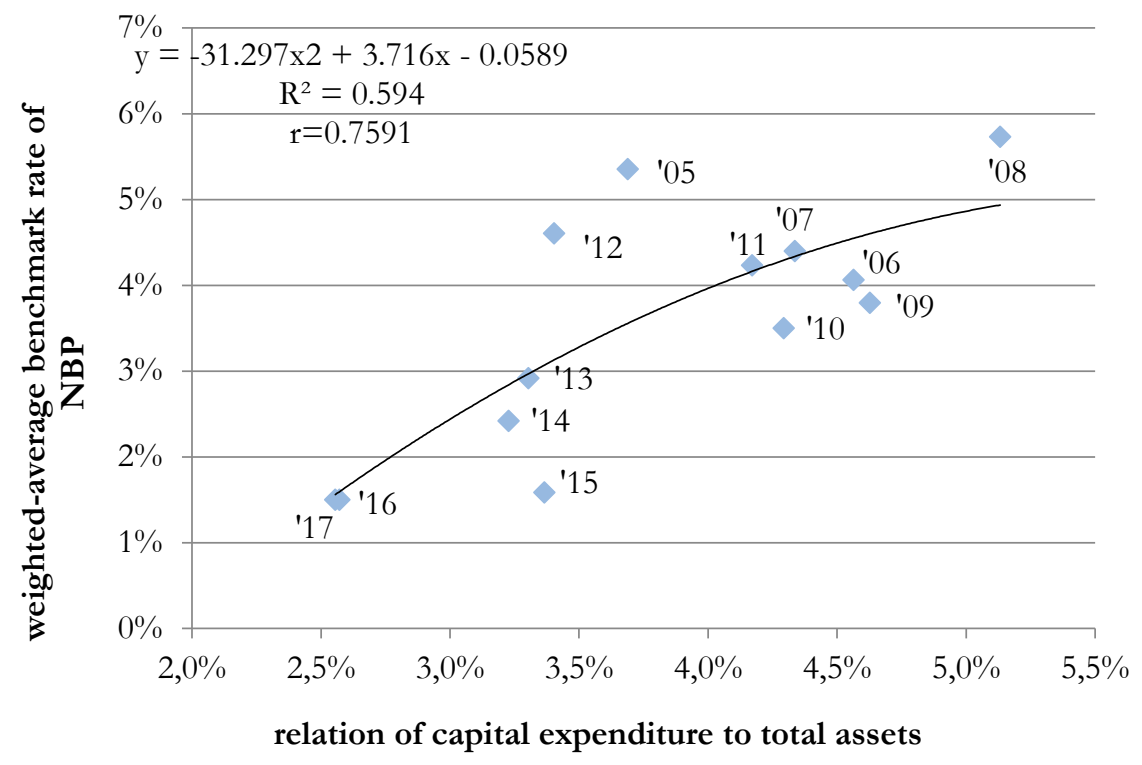

Figure 4. Average benchmark rate* of NBP vis-a-vis expenditures for fixed assets in relation to non-current assets of small businesses ** in Poland in the period 2005-2017

Source: the same as the one for Figure 1.

* weighted-average benchmark rate of NBP is a semi-annual benchmark rate of NBP weighted by a number of months of its being in effect

** with the number of employees ranging between 10 and 49 people

A considerable lower level of expenditures for fixed assets - which has persisted for several years now - of small businesses in Poland raises justified fears whether they will manage to rebuild the level of investment under the condition of an improved global economic situation and of the increased interest rate accompanying the former. Incidentally, as demonstrated earlier, an increase in interest rates is accompanied by the reduction of working capital and of the third-degree index of liquidity. This can threaten not only investments or the level of economic growth (Oprea \& Stoica, 2018) in the forthcoming years but also the competitiveness of small businesses in general.

\section{CONCLUSION}

The correlation analysis conducted herein seems to confirm the influence of a monetary policy pursued by NBP exerted on real economic indices in Poland (hypothesis no.1); and strictly speaking, on the financial policies of respective business enterprises. The change in a central bank's interest rates affects the cost of working capital, with this capital being crucial from the point of view of the financial stability of business enterprises. It is because the said capital determines the liquidity of a company and its risk, and therefore its creditworthiness, competitiveness and the key decisions made by a given business enterprise (hypothesis no. 2). That is why NBP should pay careful attention to these supply effects by establishing its own monetary policy - not only because of the influence of changes in interest rates on the level of the cost of working capital of business enterprises but also because of increasing the efficiency of a monetary policy designed, which would simultaneously translate into the economic safety of the state. Moreover, what seems necessary is better recognition of the mechanism of the cost channel in a given economy and the ongoing monitoring thereof. This will allow to set the proper balance in the following dilemma. Is it the case that due to its strength and the worse patency of the channel of interest rates, which is a 
consequence of the current low level thereof, what is needed is a more decisive reaction on the part of a central bank? Or else: is the case that due to a higher sensitivity of market interest rate anticipation (Redo, 2018a), what will prove necessary is a weaker reaction on the part of a central bank, which is aimed not only at preventing the self-fulfilling inflationary expectations but also at not stimulating the effects of the cost channel. This is particularly vital under the conditions of tension which additionally solidify the patency of the said channel.

The research results presented herein demonstrate that the business enterprises in Poland lower their liquidity in the periods in which higher interest rates are operative (more expensive capital). This threatens their financial stability, worsens their competitiveness and increases the level of working capital under the condition of lower interest rates. This in turn leads to a lower efficiency of a company's assets; and, in consequence, to the profitability which is lower than the one feasibly attainable. When the negative correlation between an interest rate of the value of working capital persists, this may threaten the financial stability of small businesses in Poland once the interest rates start - as expected - to grow. Restrictions put on funding by means of more expensive fixed capital will increases the risk of losing liquidity of business enterprises, will increase their risk premium, will worsen their creditworthiness and their credibility as business partners. Furthermore, what will get compromised is the competitiveness of small business entities, which are after all the main creators of vacancies and the main contributors to economic growth.

The above conclusions raise justified fears of the pace of economic growth of Poland in the forthcoming years; or, speaking more precisely, of Polish purported ability to rebuild the level of investment - now being considerably lower as compared to 2016 - in Poland under the possible conditions of economic upturn in global economy and the growth of interest rates accompanying it. As conclusively demonstrated above, this will most probably be accompanied by a reduction of working capital and of liquidity of business enterprises in Poland, which will in turn lead to the decrease in their financial possibilities and creditworthiness. At the same time, it should be borne in mind that what depends on financial stability of a business enterprise is the financial and economic safety of an entire economy - the stability of employment, salary rates, profits made by companies, the level of consumption, assessment of risk and development prospects, the inflow of external capital, the ability to finance one's development and to roll one's debt, and thus the future socio-economic development of Poland as well as of the future generations of Poles.

\section{REFERENCES}

Adolfson, M., Lindé, J., Laséen, S., \& Villani, M. (2005). The Role of Sticky Prices in an Open Economy DSGE Model: A Bayesian Investigation. Journal of the European Economic Association, 3(2/3), 444-457.

Barth, M. J., \& Ramey, V. A. (2000). The Cost Channel of Monetary Transmission. National Bureau of Economic Research Working Paper Series, (7675). doi: https://doi.org/10.3386/w7675

Bunea, M. \& Dinu, V. (2019). The BASEL III impact on the Romanian Banks's Solvency. Montenegrin Journal of Economics, 15(1), 189-199.

Chowdhury, I., Hoffmann, M., \& Schabert, A. (2006). Inflation dynamics and the cost channel of monetary transmission. European Economic Review, 50(4), 995-1016. doi: https://doi.org/10.1016/j.euroecorev.2005.01.007

Christiano, L. J., Eichenbaum, M., \& Evans, C. L. (2005). Nominal Rigidities and the Dynamic Effects of a Shock to Monetary Policy. Journal of Political Economy, 113(1), 1-45. doi: https://doi.org/10.1086/426038

Cieślik, E., Jankowska, E., Górniewicz, G., Piotrowicz, A., Redo, M., Redo, J., \& Siemiątkowski, P. (2015). Ekonomiczne aspekty integracii wybranych panstw Europy Środkowo-Wschodniej. Toruń: Wydawnictwo Naukowe UMK. 
Dedola, L., \& Lippi, F. (2005). The monetary transmission mechanism: Evidence from the industries of five OECD countries. European Economic Review, 49(6), 1543-1569. doi: https://doi.org/10.1016/j.euroecorev.2003.11.006

Delia Chang, J.-C., \& Jansen, D. W. (2014). Inflation Dynamics and the Cost Channel: The Small Open Economy Case. Annals of Economics \& Finance, 15(2), 325-341.

Eichenbaum, M. (1992). 'Interpreting the macroeconomic time series facts: The effects of monetary policy': by Christopher Sims. European Economic Review, 36(5), 1001-1011. doi: https://doi.org/10.1016/00142921(92)90042-U

Gaiotti, E., \& Secchi, A. (2004). Is there a cost channel of monetary policy transmission? An investigation into the pricing behaviour of 2,000 firms (No. 525). Retrieved from Bank of Italy, Economic Research and International Relations Area website: https://ideas.repec.org/p/bdi/wptemi/td_525_04.html

Goodhart, C. (1986). Financial innovation and monetary control. Oxford Review of Economic Policy, 2(4), 79-102. doi: https://doi.org/10.1093/oxrep/2.4.79

GUS. (2018). Wyniki finansowe przedsiebiorstw niefinansowych w 2018 roku. Retrieved from https://stat.gov.pl/download/gfx/portalinformacyjny/pl/defaultaktualnosci/5502/12/34/1/wyniki_finanso we_przedsiebiorstw_niefinansowych_w_2018_r.pdf

Jędrzejowska-Schiffauer I., Schiffauer P. (2016), European central bank's OMT decision: still within the framework of the monetary policy?, Journal of International Studies, Vol. 9, No 2, pp. 195-206. DOI: 10.14254/2071$8330.2016 / 9-2 / 15$

Henzel, S., Hülsewig, O., Mayer, E., \& Wollmershäuser, T. (2009). The price puzzle revisited: Can the cost channel explain a rise in inflation after a monetary policy shock? Journal of Macroeconomics, 31(2), 268-289. doi: https://doi.org/10.1016/j.jmacro.2008.10.001

Hicks, J. R. (1979). Is interest the price of a factor of production? In M. J. Rizzo (Ed.), Time, Uncertainty and Disequilibrium: Exploration of Austrian Themes. Lexington Books.

Kilponen, J., \& Milne, A. (2007). The lending channel under optimal choice of monetary policy (No. 33/2007). Retrieved from Bank of Finland website: https://ideas.repec.org/p/bof/bofrdp/2007_033.html

Mallik, G., \& Chowdhury, A. (2001). Inflation and economic growth: evidence from four south Asian countries. Asia-Pacific Development Journal, 8(1), 123-135.

Oprea, O-R. \& Stoica, O. (2018). Capital Markets Integration and Economic Growth. Montenegrin Journal of Economics, 14(3), 23-35.

Ravenna, F., \& Walsh, C. E. (2006). Optimal monetary policy with the cost channel. Journal of Monetary Economics, 53(2), 199-216. doi: https://doi.org/10.1016/j.jmoneco.2005.01.004

Redo, M. (2013). The growing importance of the risk-taking channel in the process of transmitting monetary policy. Torun International Studies, 1(6), 13-22. doi: https://doi.org/10.12775/TIS.2013.002

Redo, M. (2015). An analysis of economic changes in the countries of Central and Eastern Europe belonging to the European Union in the years 2003-2014. Torun International Studies, 1(8), 83-97. doi: https://doi.org/10.12775/TIS.2015.008

Redo, M. (2016a). Optimal monetary policy with a cost channel. Atheneum. Polish Political Science Studies, 52, 131-144. doi: https://doi.org/10.15804/athena.2016.52.07

Redo, M. (2016b). Sustaining government budget deficits as a cause for the cost of public debt service increase in Western European countries in the 1995-2015 period. Torun International Studies, 1(9), 57-65. doi: https://doi.org/10.12775/TIS.2016.005

Redo, M. (2017). Shutting down of the quantitative easing programme by European Central Bank as a threat to the market cost of capital among less credible EU member states. Torun International Studies, 1(10), 111-126. doi: https://doi.org/10.12775/TSM.2017.009

Redo, M. (2018a). Kanat oczekiwań rynkowych w procesie transmisji polityki pienię̇nej: w sytuacji coraz niższych stóp procentowych. GlobeEdit.

Redo, M. (2018b). Znaczenie skuteczności polityki pienię̇nej dla bezpieczeństwa państwa. Toruń: Wydawnictwo Adam Marszałek.

Redo, M., \& Siemiątkowski, P. (2017). External financial security of the state. Torun International Studies, O(0), 1-161. doi: https://doi.org/10.12775/TIS.2017.100 
Siemiątkowski, P. (2014). Financial dependence of the Polish economy. Torun International Studies, 1(7), 25-36. doi: https://doi.org/10.12775/TIS.2014.003

Siemiątkowski, P. (2016). The influence of the global economic crisis on the international investment position of European Union member states. Torun International Studies, 1(9), 103-110. doi: https://doi.org/10.12775/TIS.2016.009

Siemiątkowski, P. (2017). External financial security of the European Union member states outside the Eurozone. Journal of International Studies, 1(10), 84-95. doi: https://doi.org/10.14254/2071-8330.2017/10-4/6

Siemiatkowski, P., \& Jankowska, E. (2013). Financial dependence of the PIIGS countries. Journal of World Economic Research, 2(5), 89-94.

Silva, I. É. M., Paes, N. L., \& Bezerra, J. F. (2016). Evidences of incomplete interest rate pass-through, directed credit and cost channel of monetary policy in Brazil [Proceedings of the 43rd Brazilian Economics Meeting]. Retrieved from ANPEC - Brazilian Association of Graduate Programs in Economics website: https://econpapers.repec.org/paper/anpen2015/036.htm

Sims, C. A. (1992). Interpreting the macroeconomic time series facts: The effects of monetary policy. European Economic Review, 36(5), 975-1000. doi: https://doi.org/10.1016/0014-2921(92)90041-T

Tillmann, P. (2008). Do interest rates drive inflation dynamics? An analysis of the cost channel of monetary transmission. Journal of Economic Dynamics and Control, 32(9), 2723-2744. doi: https://doi.org/10.1016/j.jedc.2007.10.005

Zablotska, R. (2013). The perspectives of entry of ukrainian companies at the world market of services. Torun International Studies, 1(6), 67-78. doi: https://doi.org/10.12775/TIS.2013.007 